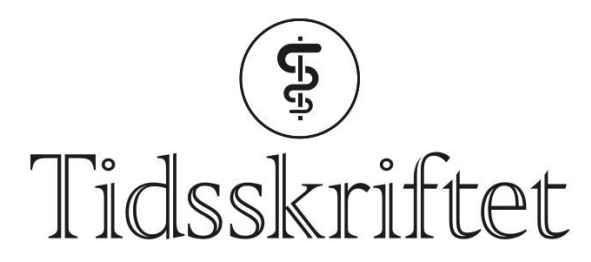

DEN NORSKE LEGEFORENING

\title{
CT-screening av lunger redder liv
}

FRA ANDRE TIDSSKRIFTER

TORBJØRN ØYGARD SKODVIN

Tidsskriftet

CT-screening av røykere gir redusert dødelighet, viser studie.

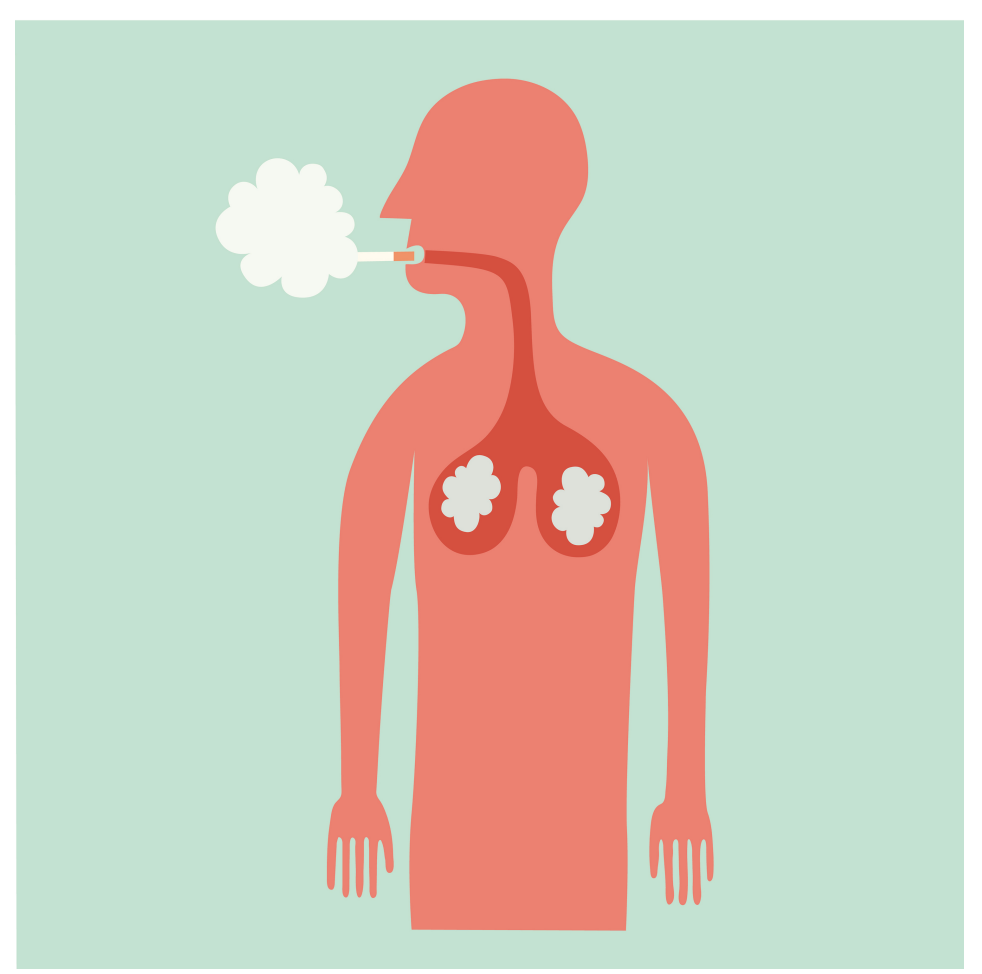

Illustrasjon: amathers/iStock

Lungekreft er kreftsykdommen som tar flest liv, både i Norge og i verden. I en multisenterstudie fra Nederland og Belgia ble rundt 13 ooo menn og 2600 kvinner $i$ alderen 50-74 år og som var røykere eller tidligere røykere, randomisert til fire lavdose CTundersøkelser av lungene over fem år eller ingen screening (1). Etter ti år var insidensen av lungekreft i de to gruppene henholdsvis 5,58 og 4,91 tilfeller per 1 ooo personsår. Antall lungekreftdødsfall var henholdsvis 2,5 0g 3,3 per 1000 personår, dvs. en reduksjon på $24 \%$ (kumulativ rateratio o,76; $95 \% \mathrm{KI}$ o,61-0,94; $\mathrm{p}=0$,01). For kvinner var reduksjonen enda større, men ikke statistisk signifikant, antakelig pga. antallet personer.

- Denne studien viser at vi nå har solid evidens for at CT-screening kan redusere dødeligheten av lungekreft, sier Haseem Ashraf, som er førsteamanuensis ved Universitetet i Oslo og overlege ved Bildediagnostisk avdeling, Akershus universitetssykehus. 
- Norsk lungekreftgruppe arbeider for å få et etablert et screeningprogram for lungekreft også i Norge, forteller Ashraf. Basert på bl.a. denne studien er det grunn til å tro at over 500 liv kan reddes fra død av lungekreft dersom alle røykere eller tidligere storrøykere i befolkningen gjennomgår lavdose CT-undersøkelse av lungene, sier Ashraf.

\section{LITTERATUR:}

1. de Koning HJ, van der Aalst CM, de Jong PA et al. Reduced lung-cancer mortality with volume CT screening in a randomized trial. N Engl J Med 2020;382: 503-13. [PubMed][CrossRef]

Publisert: 25. mai 2020. Tidsskr Nor Legeforen. DOI:10.4045/tidsskr.20.0175

(C) Tidsskrift for Den norske legeforening 2020. Lastet ned fra tidsskriftet.no 